\title{
Apontamentos sobre Bernardo Élis biógrafo (1973-1980)
}

\author{
Notes on Bernardo Élis biographer
}

\author{
Albertina Vicentini Assumpção \\ Doutora em Teoria Literária Comparada \\ Professora Titular da Pontifícia Universidade Católica de Goiás \\ albertinavicentini@uol.com.br
}

Gabriel de Paula

Doutorando em História pela Universidade Federal de Goiás Professor do Instituto Federal de Goiás gabriel.paula@edu.ifg.br

Resumo: $O$ artigo objetiva apresentar, suscintamente, algumas modalidades de escrita de Bernardo Élis no exercício de biógrafo de vultos goianos, especialmente a sua biografia do General Xavier Curado. Insiste nos tons e na patrimonialização cedidos aos biografados e na autolegitimação do biógrafo. Uma questão central na obra de Bernardo Élis é o desejo de inclusão da região goiana no contexto nacional. A literatura de Élis busca reduzir a distância entre o litoral e o sertão. Suas obras caminham no sentido de pensar o Brasil de forma mais ampla, escapando do monopólio narrativo do centro-sul.

Palavras-chave: História, biografia, Xavier Curado, Bernardo Élis.

\begin{abstract}
This paper aims to present, concisely, some types of Bernardo Elis in the exercise of biographer goianos figures, especially his biography of General Xavier Curado. Stresses the tones and its patrimony assigned to biographees and self-legitimation of the biographer. A central issue in the work of Bernardo Elis is the desire to include the Goiás region in the national context. The Elis literature seeks to reduce the distance between the coast and the hinterland. His works go towards thinking about Brazil more broadly, escaping the narrative monopoly of the centersouth.
\end{abstract}

Keywords: History, biography, Xavier Curado, Bernardo Élis. 
Conforme já abordado em outro artigo (VICENTINI, 2005), Bernardo Élis foi um literato de variadas faces. Foi escritor de inúmeros ensaios culturais e sociológicos sobre o país e Goiás, pesquisas históricas e debates, álbuns de fotografia e artes plásticas, crônicas jornalísticas e discursos, romances, novelas, poesias, dezenas de contos. E sua bibliografia extensa e variada, se reproduziu não só em diferentes teses, dissertações, monografias, ensaios, artigos locais e nacionais, como também frequentou as linhas da crítica, antologias, seletas, perfis biobibliográficos de autores atuais, o cinema, a televisão e as traduções alemã e inglesa.

Diante disso, faremos breves comentários generalizados sobre sua obra, buscando mostrar algumas de suas faces, especialmente a do historiador na modalidade biógrafo. Apontaremos algumas modalidades de sua escrita nesse sentido e nos deteremos na sua principal biografia sobre o General Xavier Curado.

De modo geral, parece que o tema da desalienação pode ser um dos elementoschave dessa face, motivado talvez por sua participação no Partido Comunista Brasileiro, para o qual a consciência de classe e, pois, a desalienação do homem da ideologia da classe dominante sempre foi uma premissa. Haja vista que, pelo menos naquilo que queremos destacar aqui, esse parece ser um tema central a recobrir a sua matéria escrita: tanto a face do Bernardo Élis historiador, na qual se insere a do biógrafo, quanto de sua face literária propriamente dita, todas elas inscritas dentro do regionalismo que professou.

Em princípio, parece ser para ele obrigação do intelectual dar a conhecer ao povo goiano parte de sua história, ou seja, desaliená-lo e conscientizá-lo de sua própria história. Tal motivação ${ }^{1}$ parece ter levado Bernardo Élis ao exercício de biógrafo em crônicas e monografias, à pesquisa, documentação e registro sobre os vultos da cultura goiana, sua história e contribuição para o estado e a nação, além de certo anedotário regional de censos e procedência de determinados vocábulos e denominações; também sobre a vida e a obra de poetas e intelectuais goianos ou não, como Félix de Bulhões, Octo Marques, Bartolomeu Cordovil; seus testemunhos e depoimento sobre Pedro Gomes, Altamiro de Moura Pacheco e outras personalidades goianas; as crônicas circunstanciais publicadas nos jornais locais; e seus artigos e ensaios literários sobre os goianos Eli Brasiliense, Vitor de Carvalho Ramos, Hugo de Carvalho Ramos, Leo Lynce e sobre os nacionais Monteiro

\footnotetext{
${ }^{1}$ Diz ele, em uma de suas crônicas - "Goiana, a mãe de Álvares de Azevedo" (ÉLIS, 1987, v. 4: 158): "Sempre que se me depara, por informação oral ou através da leitura, qualquer curiosidade histórica que se relacione com Goiás, dificilmente consigo dominar a vontade de torná-la pública por meio de qualquer veículo de comunicação, para conhecimento dos que se interessam pelas coisas do passado".
} 
lobato, Josué Montello, Afonso Arinos, Tristão de Ataíde, Valdomiro Silveira, Paulo Dantas, para só citar alguns. Em consonância com vários autores da literatura nacional no período pós-1930, Bernardo Élis cerrou as fileiras do Partido Comunista do Brasil (PCB).

O engajamento partidário era apenas uma das entradas de Élis no movimento comunista. Leitor de obras sobre o socialismo e o comunismo, esteve em contato com autores como Plekhanov, Talheimer, Rosa Luxemburgo, M. Rosenthal e outros (RM-IELUNICAMP). Tendo trabalhado em órgão do governo do Estado de Goiás, voltado para o Cooperativismo, teve contato com a noção de lucro, mais - valia e outros elementos do discurso marxista (RM-IEL-UNICAMP). Realizando graduação em Direito, e percebendo que o discurso dominante no meio era o Católico, se armou com leituras de René Worms, Ludgero Jaspers, Charles Lahr e Deão de Cantuária, com a obra $\mathrm{O}$ poder soviético (1946). Essa entrada no pensamento de esquerda permitiu que Élis ficasse "convencido de que o marxismo, o comunismo, seria uma renovação para a humanidade, bem como a psicanálise, sem embargo das contradições entre as duas doutrinas" (RMIEL-UNICAMP).

De outro lado, um dos grandes esforços de Élis consistia na tentativa de inserir Goiás de forma mais ampla no cenário nacional, em particular na esfera cultural. Sua tentativa de concorrer para uma cadeira na Academia Brasileira de Letras na década de 1970 evidencia tal projeto. Em carta enviada por João Cabral de Melo Neto no dia 20 de junho de 1973, o escritor pernambucano reflete sobre a candidatura de Élis a uma cadeira na Academia Brasileira de Letras:

\footnotetext{
Meu caro Bernardo Élis, recebi a carta em que me comunica sua candidatura à Academia. Tenho a maior simpatia por você, sem conhecê-lo, e por sua obra, da qual conheço os livros que me mandou e outros textos que nosso amigo Willian Agel de Melo me deu a ler em Barcelona. Estou de partida para o Brasil, onde espero chegar no dia 2. Assim, estarei presente à eleição. Não me comprometo a votar em você porque essa eleição me parece muito difícil e impossível de ser avaliada por quem está de longe, sem notícias concretas. Esperando, ter a oportunidade de votar em você, se não desta vez, muito proximamente... (MELO NETO, 1973, s.p.).
}

A campanha pela entrada na Academia Brasileira de Letras teve início ainda em 1968, ao pleitear a vaga de Guimarães Rosa. Cassiano Ricardo, em carta de 10 de agosto de 1968, diz a Élis que "sua carta sobre o assunto só me chegou às mãos quando já havia eu assumido compromisso com outro candidato" (CEDAE/IEL). Na mesma linha, 
Fernando de Azevedo diz não ter ainda situação de voto em Bernardo por não ter ainda tomado posse de sua cadeira na Academia (CEDAE/IEL). A mobilização da intelligentsia fracassou num primeiro momento e se arrastaria até outubro de 1975, quando foi eleito, tomando posse em 10 de dezembro do mesmo ano.

No entanto, essa mesma postura de historiador localizada na biografia de vultos goianos e na história de Goiás, por sua vez, também parece ser proveniente tanto de sua defesa inconteste do regionalismo em literatura (são vários os ensaios ${ }^{2}$ que ele dedica ao tema) como de sua participação na vida cultural do estado e da nação, principalmente através de sua participação tanto nas academias goiana e brasileira de letras quanto nos jornais locais e revistas (desde a revista Oeste, de $1942^{3}$ ).

Dizemos isso porque grande parte desse seu feitio de obra é resultado de discursos na Academia, conferências, crônicas e de ensaios jornalísticos "celebrativos" e/ou chamativos sobre personalidades e obras culturais pertinentes a esse tema. Disso parece, em parte, resultar essa face "bernardiana" que queremos apontar aqui: a do Bernardo Élis biógrafo.

\section{A biografia}

A biografia, sabe-se, é um discurso de um terceiro sobre um primeiro - um outro - e situa-se sempre entre o discurso do testemunho, o da ficção e o do relato histórico. Se prima sobre a autobiografia, é, no entanto, tão controverso quanto esta, acrescentado o fato de que se situa na fronteira do literário e do jornalístico. Frequentemente inspirada na devoção ao personagem biografado, tratado, pois, como herói ou heroína, a biografia, pelo menos nessa perspectiva, inventa um tempo narrativo, ajusta o tempo cronológico pelas etapas da vida do biografado, relevando seus méritos, mas também a sua vida secundária capaz de explicar cada um desses méritos. É um gênero discursivo que está sempre ameaçado "desde as origens, entre a admiração e a objetividade, entre uma suposta 'verdade' a restaurar e o fato de que toda história é apenas uma história a mais a ser contada sobre um personagem" (ARFUCH, 2010: 138). O maior risco de um biógrafo é o de tornar sua biografia "monumento, exercício de erudição, obsessão de arquivo ou

${ }^{2} \mathrm{O}$ principal desses ensaios é "Tendências regionalistas do Modernismo" (ÉLIS, 1987, v. 4).

${ }^{3}$ A revista Oeste foi uma publicação do Estado Novo brasileiro em Goiás (que ela defendeu) e que saiu de 1942 a 1944, com 23 números. Foi republicada pela Ed. UCG com apoio da Caixa Econômica Federal, por um projeto do escritor José Mendonça Teles. Oeste (2001) - Revista Mensal. [Livro em CD-Rom]. Agência Goiana de Cultura "Pedro Ludovico Teixeira" - AGEPEL. 
inventário de mínimos incidentes 'significantes', transformando-se [em saudação descabida ou até] em estilete contra o seu objeto" (Idem:139). Nesse último sentido, o do estilete, aparecem as biografias que, ao contrário das devotas e admirativas, tendem a denegrir o biografado, apresentando-o em suas facetas mais íntimas e desagradáveis, o que não invalida o fato afetivo - amor ou ódio - que impulsiona, em parte, quase todas as biografias. Ao contrário, modernamente, as aproxima mais do jornalismo inclusive, satisfazendo algumas motivações do público-leitor, entre elas o desconhecimento, a curiosidade, a compaixão, a análise distanciada, a admiração", a raiva etc. Ou a busca daquele algo mais que ilumine o contexto vital da figura de algum modo conhecida dificilmente se lê a biografia de um personagem que se desconhece" (Idem:140)

De outro lado, a relação entre história e biografia é antiga, debatida e imprecisa (LORIGA, 1996: 226): "Decepcionados e insatisfeitos com o uso de categorias interpretativas predeterminadas, os próprios historiadores sociais, tradicionalmente mais atentos à dimensão coletiva da experiência histórica, começaram a refletir sobre os destinos individuais".

A retomada da biografia como tema da escrita da história seria, na visão de alguns, um forte indicativo do abandono da história-problema e da transformação da "história em migalhas": os riscos de uma narrativa linear, cronológica, onde o tempo de uma vida corresponde ao objeto, seria uma afronta ao caráter analítico (e geral) da história. Ao realizar os trabalhos da biografia de São Luís, Jacques Le Goff dizia estar desolado com o caráter de certas biografias: "superficial, anedótico, puramente cronológico, que se sacrifica a uma psicologia ultrapassada, incapaz de mostrar a significação histórica geral de uma vida individual” (LE GOFF apud LORIGA, 1996: 226).

Mas há também as questões do mercado: "a vitalidade da biografia como gênero se explica sem dúvida, entre outros fatores, pelo fato de jogar com uma variedade de públicos e também com uma gama muito vasta de compradores que vão além do meio dos historiadores profissionais", como diz Jacques Revel (2010: 235).

O mercado editorial das biografias é sempre balançado com as efemérides, datas cívicas ou aniversário de grandes personagens históricos. Porém, como bem afirma Revel (2010: 239), “a biografia histórica não se tornou por isso um exercício livre”. Quer dizer, além da presença da fonte como chave fundamental para a escrita, outros elementos como coesão, testemunhos e uma narrativa fluida e envolvente são essenciais, inclusive ao próprio mercado. Fugindo da historia magistra vitae, os novos regimes de historicidade apontam para a impossibilidade do exemplo que perpassa os tempos tornando-se um 
continuum. E, nessa perspectiva, "o que está no coração do projeto biográfico é a importância de uma experiência singular mais que a de uma exemplaridade destinada a encarnar uma verdade ou um valor geral, ou ainda a convergir com um destino comum" (REVEL, 2010: 242).

De seu lado, também Pierre Bourdieu já assinalou o paradoxo da biografia no ‘absurdo’ ou na ilusão (a artificialidade, a arbitrariedade e a fabricação) do relato de vida, ou seja, a perspectiva de contar a vida de um sujeito unitário, atrás de quem está uma filosofia da história cujo conceito se aninha na narrativa e na noção sartreana de "projeto original" de vida, ou seja, uma intenção subjetiva ou objetiva ("sempre gostei de música", dizem inúmeros biografados). Como narrativa, para ele, a biografia sofre todas as convenções desta: extrair uma lógica retrospectiva e prospectiva, "estabelecendo relações inteligíveis, como a do efeito à causa eficiente e final, entre os estados sucessivos, em etapas de um desenvolvimento necessário" (BOURDIEU, 1996: 184): em outras palavras, a velha lógica aristotélica da conexão necessária e lógica - plausível - entre os atos, que toda narrativa realiza para ser uma narrativa (e a que Hayden White veio completar com os seus tropos discursivos). É que a vida, afinal, é uma anti-história, ou seja, “o real é descontínuo, formado de elementos justapostos sem razão, todos eles únicos e tanto mais difíceis de serem apreendidos porque surgem de modo incessantemente imprevisto, fora de propósito, aleatório" (Idem: 185 - citando Robbe-Grillet).

De todo modo, biografias existem (autobiografias também) talvez reunidas pelo princípio do habitus que unifica práticas e representações de grupos em séries que podem ser retomadas por discursos/relatos mais totalizantes, encabeçados, segundo Bourdieu, pelo nome próprio ou pela nominação, que é o único veículo visível que situa o sujeito historicamente num tempo, num espaço e lhe determina uma identidade social constante e durável e que garante o mesmo indivíduo em todos os campos onde ele intervém como agente.

Em certo sentido, portanto, diz Bourdieu, a biografia tende a aproximar-se do modelo da apresentação oficial de si, "biografia oficial" e da filosofia da identidade que a sustenta, afastando-se das trocas íntimas, da confidência, dos diários íntimos. Por isso varia "segundo a qualidade social do mercado em que é oferecida" (Idem: 189), porque é uma apresentação pública de uma representação privada, o que aumenta o número de coações específicas.

Isso torna relevante o como Bernardo Élis construiu seu discurso de biógrafo: tendo em vista destinatários específicos - os acadêmicos da Academia Goiana e Letras, 
os leitores de jornais locais, os estudantes em conferência etc. e explicando suas coações e suas dominantes e essas últimas bastante variadas, indo desde a biografia ligeira, feita a partir de entrevistas e mais dentro do gênero crônica ou discurso, até a "biografia oficial", como a que ele elaborou para seu parente General Xavier Curado, que nos interessa mais de perto e que aponta uma face peculiar de um Bernardo Élis biógrafo.

\section{Algumas modalidades de biografias bernardianas}

Um primeiro modo seria, por exemplo, quando constrói os traços da personalidade de Altamiro de Moura Pacheco ${ }^{4}$, o conhecido vulto goiano, intelectual solteiro, rico e recluso. Bernardo Élis inicia esse modo pelo espaço da casa do biografado (tentando, como Balzac, indiciar o seu personagem pelos apetrechos que mantém em casa, pela arquitetura da casa etc.), configurando um "como" explicitamente realista, de um lado, e totalmente avaliativo, de outro, avaliação que faz aparecer o biografado em sua intimidade do lar, mas também em sua intimidade moral e de comportamento social, econômico etc.

A residência do Sr. Altamiro de Moura Pacheco (...) situada na esquina da rua Quinze com a Av. Araguaia, ela ergue altaneiramente sóbria na severidade quase humilde de suas linhas retas, de suas esquadrias de ferro, na brancura meio hospitalar do cimento que reveste a parte inferior, inclusive os muros de fino gradil de ferro. Discretamente, oculta-se por trás de palmeiras e outras árvores, ocupando a área de dois lotes, nos quais, sem isolar-se acintosamente, mantém uma cristã tolerância para com a proximidade sempre algo incomodatícia dos vizinhos.

O interior sublinha os traços de sóbria fidalguia: o alpendre amplo, grandes salões atapetados, mobiliados com escassez (...) tudo velado pelas persianas baixadas, em cuja penumbra algum quadro de bom tom coloca visões de plagas estrangeiras - um castelo feudal, um mar encapelado, uma camponesa saudável. Domina o tom escuro, levemente avermelhado de móveis e metais, numa recordação de sacristia. Ausência de santos e mulheres.

\footnotetext{
${ }^{4}$ Vulto goiano, nascido em Bela Vista-Go (15.03.1986 - 10.06.1996), responsável pela desapropriação do quadrilátero onde Brasília-DF seria edificada, fundador do Banco Agropecuário de Goiás doador de inúmeras propriedades e terras onde se instalariam, por exemplo, o Aeroporto Santa Genoveva, a Academia Goiana de Letras e o quartel do Exército em Goiás (TELES, 2000).
} 
(...) No vasto salão que a parcimônia dos pesados móveis torna maior, como que o relógio cresce e impõe (...) um ritmo diferente daquele ritmo tumultuário que domina a avenida fora. No sobrado estão dois apartamentos (...) também aí estão dois amplos salões de paredes totalmente recobertas por estantes de livros que vão até o teto alto; os volumes enchem ainda as prateleiras dispostas no hall aonde desemboca a escada (..)

(...) a mais numerosa e rica biblioteca particular (quiçá pública) do Estado de Goiás: aproximadamente 10.000 exemplares, abrangendo obras dos mais diferentes e díspares gêneros, assuntos, idiomas ${ }^{5}$... (ÉLIS, 1987, v. 4: 104105).

Depois, institui sua personalidade de homem rico (quando os antecedentes de homem que enriqueceu por si só vêm à tona):

(...) à direita da porta de entrada, numa escrivaninha de fechar, é que Dr. Altamiro se conserva escrevendo suas notas, lendo ou fazendo as contas e alinhando as cifras que traduzem o estado de seus negócios grandes e vultuosos: o numeroso rebanho de alta mestiçagem, as colheitas das terras ( as melhores do Estado) de sua enorme fazenda pegada a Goiânia, os loteamentos de terrenos, etc.,etc.. Se do lado direito está a escrivaninha, do outro fica o cofre - verde, mudo silente e esguio como um guarda prussiano (...). Jovem pobre, teve nosso pseudo-entrevistado que ganhar dinheiro para depois formar-se, ao contrário da regra geral (...) Em 1933, quando se diplomou médico pelo Rio de Janeiro, contava 37 anos de idade, já era formado em Farmácia por Goiás e possuía regular fortuna consubstanciada em mais de uma farmácia (...) (ÉLIS, 1987, v. 4: 106).

Para, a seguir, nomear suas características morais de homem sóbrio, solteirão, e generoso, dessa feita inclusive através de relatos específicos que testemunhou ou de que foi o protagonista, como na anedota do livro emprestado ${ }^{6}$ ou como nos "empréstimos" dados a algumas mulheres e homens, "seres estragados pela vida (...) que não têm

\footnotetext{
${ }^{5}$ Observar que a fidalguia, a nobreza de caráter, a severidade, a intelectualidade e a reclusão do biografado já se encontram adjetivados e metaforizados na descrição da casa.

${ }^{6}$ Élis conta de um livro que tomou emprestado de Altamiro e que repassou a um professor de Brasília que foi demitido e só devolveu o livro bom tempo depois. A aflição de Élis teria vindo do fato de que Moura Pacheco não emprestava seus livros a ninguém (embora abrisse sua biblioteca à comunidade para pesquisa e estudo) e havia, por amizade generosa, feito uma exceção a ele (ÉLIS, 1987, v. 4).
} 
condições de usar Bancos, caixas ou instituições de crédito e vêm se valer do espírito humanitário e compreensivo do velho clínico Dr. Altamiro de Moura Pacheco" (Idem: 112). Um empréstimo que Élis qualifica de muito estranho e original, porque "não tem retorno, mas que se chama empréstimo para não arrancar àqueles pobres entes seus derradeiros sentimentos de dignidade (...)" (ÉLIS, 1987, v. 4: 114).

No caso de Altamiro, portanto, Élis monta uma biografia metafórica, nos moldes explicados por Hayden White (1995), especialmente a partir do testemunho (era um amigo), o que a tornará "verídica" e, por conseguinte, correta.

De outras vezes, sua biografia ergue o patético (e o trágico) em cima das dificuldades do biografado, como no caso da biografia de Octo Marques ${ }^{7}$, cujas dificuldades de infância, pobreza e descaso não testemunhou, mas lhe foram confidenciadas pelo próprio biografado, construindo assim uma biografia justificatória do parco espaço cedido ao artista no meio cultural goiano.

Exercendo um modesto cargo de escriturário da fazenda pública estadual, que lhe dá menos de 300 cruzeiros mensais, o pintor se vê na contingência de ter que suplementar a receita com a vendagem de suas pinturas. O diabo, porém, é que Octo é muito conhecido, todo mundo é seu amigo, e quer os quadros dados ou quer pagar quantias insignificantes, situação que não lhe permite obter um rendimento mais substancioso, apesar de algumas pessoas o quererem auxiliar... (ÉLIS, 1987, v. 4: 30).

Após contar-nos das dificuldades de Octo Marques nas primeiras pinturas, depois como pintor de ex-votos, suas colaborações em revistas nacionais, suas primeiras pinturas a óleo, sempre dependente de um "padrinho" ou de um "amigo", Élis termina por indiciar que o seu relato foi fruto de uma entrevista/confidência. Diz-nos que Octo ainda espera que

os amigos que ele possui desde os mais ínfimos postos da administração até o pináculo da glória não se esqueçam de melhorar sua posição no quadro do

\footnotetext{
${ }^{7}$ Nascido na cidade de Goiás (08/10/1915). Pintor, desenhista, escritor, ceramista e gravador. Notabilizouse por retratar a cidade de Goiás em seus ícones e vida cotidiana. Fundador do Curso de Artes Plásticas na Escola de Belas Artes Veiga Valle, revisor do jornal O Estado de São Paulo e colaborador e ilustrador da revista Vida doméstica do Rio de Janeiro (TELES, 2000).
} 
funcionalismo estadual de modo a permitir-lhe algum sossego no campo das finanças.

- Você acha que estou querendo demais? - me pergunta o pintor na sua humilde ingenuidade (ÉLIS, 1987, v. 4: 34).

Aliás, normalmente, é por meio do testemunho ou da confidência ou entrevistas que esse tipo de biografia se constrói, uma biografia que não leva muito em conta o contexto sócio-político ou histórico, mas as "vicissitudes" da vida do biografado. Quase sempre, nessas, é o anedotário ou o testemunho que aponta para a personalidade, essa que, em certo sentido, é a procura do que se quer transmitir do biografado.

Outras biografias de Élis (quase semibiografias) são mais analíticas, especialmente as de autores literários, cuja análise de obra é repassada ao leitor em sua matéria, e, principalmente, em sua estilística, com análises argutas, bem enquadradas e que revelam um Bernardo Élis conhecedor de teoria literária, que cita autoridades da crítica, da teoria e da literatura propriamente dita. Estão nesse teor, por exemplo, a biografia de Eli Brasiliense ${ }^{8}$, ou a de Monteiro Lobato ${ }^{9}$

Mas a biografia que ressalta em sua postura de biógrafo é a que elaborou para o seu parente Tenente-General Joaquim Xavier Curado (1746-1830). Desde a genealogia familiar em Meia Ponte, nos idos da Colônia do século XVIII, até a Independência de 1822, Xavier Curado é o fio condutor de uma narrativa linear, unitária, de um personagem que se mantém constante em atitude e personalidade: firme, correto, honesto, corajoso, pertinaz, arguto etc. como a avaliar, moralmente, a própria genealogia e a ancestralidade dos Xavier Curado [Fleury, Caiado, Bulhões] a que pertence o biógrafo.

\footnotetext{
${ }^{8}$ Obras: Pium (1949); Bom Jesus do Pontal (1954); Chão vermelho (1956); rio Turuna (1964); O irmão da noite (1968); Um grão de mostarda (1969); A morte do homem eterno (1970); O perereca (1974);Uma sombra no fundo do rio (1977); A cidade sem sol e sem lua (1977).

${ }^{9}$ Obras: O Saci-Pererê: resultado de um inquérito (1918); Urupês (1918); Problema vital (1918); Cidades mortas (1919;) Ideias de Jeca Tatu (1919); Negrinha (1920);A onda verde (1921); O macaco que se fez homem (1923); Mundo da lua (1923); Contos escolhidos (1923); O garimpeiro do Rio das Garças (1924); O Presidente Negro/O choque das Raças (1926); Mr. Slang e o Brasil (1927); Ferro (1931); América (1932); Na antevéspera (1933); Contos leves (1935); O escândalo do petróleo (1936); Contos pesados (1940); O espanto das gentes (1941);Urupês, outros contos e coisas (1943); A barca de Gleyre (1944); Zé Brasil (1947); Prefácios e entrevistas (1947);Literatura do minarete (1948); Conferências, artigos e crônicas (1948); Cartas escolhidas (1948); Críticas e outras notas (1948); Cartas de amor (1948).
} 


\section{A biografia de Joaquim Xavier Curado}

A perspectiva aberta por Revel (2010: 242) sobre a importância da biografia como "uma experiência singular mais que a de uma exemplaridade destinada a encarnar uma verdade ou um valor geral, ou ainda a convergir com um destino comum" pode ser um bom ponto de partida da biografia de Joaquim Xavier Curado. No texto de Élis, existem vários indicativos de que ele busca uma experiência singular na figura de Xavier Curado. Estando Goiás vivendo uma era de crise fruto da mineração, na passagem para o século XIX, o jovem Curado "nesse quadro tão sombrio [..] mostrava viva inteligência, que o pai ainda em vida pretendia aproveitar, fazendo-a aperfeiçoar-se na famosa Universidade de Coimbra" (ÉLIS,1987, v. 5: 22).

A sua leitura busca identificar um caráter excêntrico no jovem goiano, fugindo às determinantes geográficas - haveria, em Goiás, mentes educadas e cultas frente à crise , dado que, seguindo caminho diferente do imaginado pelo pai, Xavier Curado, aos 18 anos de idade, alistou-se no Exército Real, com a patente de soldado nobre. Rapidamente, entre 1765 e 1770, no entanto, atingiu as divisas de galão de alferes e a sua carreira militar é narrada por Élis tendo sempre em vista o seu enquadramento nos limites da História do Brasil, isto é, ultrapassando os limites da "província” ao mesmo tempo em que leva Goiás adiante com seu filho ilustre.

A primeira grande ação militar de Curado e que se transformará em seu ápice heróico em campanhas na região da bacia do Prata é assim narrada por Élis:

Conseguiu Xavier Curado salvar os ditos fazendeiros e moradores de tanta opressão, e restabeleceu a paz e a tranquilidade de que se achavam privados, com toda a prudência e moderação empregando um corpo de tropas que formou de diversos moradores para as diligências que fossem necessárias, para rechaçar os que se tornassem indomáveis, com o que fez - respeitando em muitas e repetidas ocasiões e lugares em que se praticaram aquelas irrupções $(1987$, v. 5: 35).

A leitura do trecho não guarda dúvida sobre o caráter laudatório: Curado era um arauto da dignidade e da honradez, dotado das mais sublimes virtudes. E, se essas virtudes são morais, elas são complementadas pela página também digna de nota em que Élis narra a indicação de Xavier Curado para comandar a Academia Militar em 1799 (ÉLIS, 1987, 
v. 5: 38): "Essa posição de Xavier Curado à frente da primeira Academia define sua qualidade de homem não apenas ligado às armas, mas ligado principalmente às ideias, ao pensamento, às diretrizes culturais que deviam nortear o mundo militar".

O "homem de pensamento" ainda é louvado em meio aos problemas na fronteira com as áreas hispânicas no extremo sul, quando o governo português envia o Coronel Xavier Curado para a resolução dos problemas: "atendendo a tudo isto, para lá envia o Vice-Rei um dos mais inteligentes, cultos, hábeis, corajosos e leais oficiais do exército" (ÉLIS, 1987, v. 5: 44).

Como governador de Santa Catarina, assumindo o cargo em 1800, o seu lado público-administrativo louvável comparece:

Realizou Xavier Curado numerosos trabalhos públicos. Aos moradores mandou entregar títulos de propriedade das terras que haviam desde o estabelecimento dos casais açorianos, seus antepassados, regularizando sua situação. Apesar de ter iniciado o seu governo de forma despótica, modificou sua conduta e conseguiu realizar uma administração que se caracterizou pela ordem, pela paz, e pela justiça, tornando-se querido e admirado da população (CABRAL apud ÉLIS, 1987, v. 5: 44).

Após anos de serviços prestados na região platina, contando com 74 anos de idade, o General Xavier Curado fixou-se no Rio de Janeiro, chegando em agosto de 1820. Nas palavras do biógrafo, "embora idoso, o incansável militar não se entregou ao ócio ou ao descanso a que tanto direito tinha...” (ÉLIS,1987, v. 5: 97). Tornou-se, doravante, possuidor de assento no Supremo Conselho Militar de Justiça.

A situação no império luso era instável: frente ao avanço dos ecos do liberalismo, que não foram abafados pelo Congresso de Viena (1814-1815), eclodira em Portugal a Revolução Liberal do Porto (1820). Entre 1821 e 1822, os acontecimentos políticos em Portugal e no Brasil conduziram ao cenário da emancipação brasileira e, à época da realização da biografia de Xavier Curado, início dos anos 1970, a historiografia nacional debatia a crise do antigo sistema colonial, trabalhada por Fernando Novais ${ }^{10}$. Frente aos desdobramentos do dia do Fico (9 de janeiro de 1822), Bernardo Élis (1987, v. 5: 123)

\footnotetext{
${ }^{10}$ Em obra clássica, intitulada Portugal e Brasil na crise do Antigo Sistema Colonial (1777-1808), Fernando Novais apresenta as contradições inerentes ao sistema absolutista e imperial lusitano, no quadro amplo de uma crise de proporções globais (NOVAIS, 2011).
} 
afirma que "é de se crer que a resolução de organizar forças militares capazes de garantir a resolução do príncipe tenha sido iniciativa do General Xavier Curado". Sobre a decisão do Príncipe Regente, contando com o apoio de Curado e outros militares, como Oliveira Álvares e Nóbrega, Élis (1987: 123) também diz: "nascia o exército brasileiro, ao calor das lutas patrióticas, numa profunda confraternização de civis e militares e religiosos e comerciantes e estudantes e gente do povo". E, claramente inventando a tradição (HOBSBAWM, 2008), Bernardo Élis reafirma:

A idéia de que ao General Xavier Curado cabe com honra o título de CRIADOR DO EXÉRCITO BRASILEIRO é repetida no editorial com que o jornal 'O País', noticia o aparecimento do primeiro volume do livro de A. Pretextato Maciel, transcrito à página 9 do segundo volume, quando diz: '1822, data em que se pode considerar formado o núcleo do nosso exército com os militares que compareceram à reunião do povo e tropa, efetuada no campo de Santana, a 12 de janeiro daquele ano, sob a direção dos Generais Oliveira e Xavier Curado (1987, v. 5: 124).

Tendo papel de importância na tentativa de coibir a insubordinação da tropa portuguesa frente à decisão da permanência do Príncipe Regente, Xavier Curado (já com a patente de General): “Respondeu que os brasileiros estavam ali para defender o Príncipe e a cidade e que não largariam as armas enquanto o Príncipe e a cidade se achassem ameaçados pela oposição hostil que tomara a tropa portuguesa" (ÉLIS, 1987, v. 5: 126).

E, em meio às turbulências do mês de janeiro de 1822, "era o General Curado o verdadeiro comandante das tropas, Supremo e único pelo seu posto de mais graduado e por único nomeado pelo Príncipe" (ÉLIS, 1987, v. 5: 132). Contudo, vale ressaltar que, na opinião de Bernardo Élis, o fato de Xavier Curado ter sido preterido à pasta da guerra, deve-se ao fato de ser brasileiro. O seu argumento se constrói no sentido de dissuadir a opinião então recorrente de que "a muitos pode parecer que a não inclusão do nome do General Xavier Curado na pasta da guerra, como seria natural, significaria representar ele uma grandeza menor dentro do exército e no correr dos acontecimentos" (1987, v. 5: 132).

Em resumo, o relato do biografado, após a genealogia, vai desde suas primeiras letras ao seu ingresso no exército real aos 18 anos, os feitos e méritos que o fizerem escalonar ou subir na hierarquia da carreira militar no decorrer da maturidade-combate a índios amotinados na Paraíba, execução de Tiradentes, governador de Campos dos 
Goitacazes (Santa Catarina), primeiro diretor da Academia Militar, duas missões secretas no Prata - até a velhice, como comandante em todas as investidas da Guerra Cisplatina contra Artigas, posse no Supremo Conselho Militar, participação junto a D. Pedro nos levantes anteriores e posteriores ao Fico, na Independência e, afinal, Governador das Armas da Província do Rio de Janeiro e da Corte, quando é elevado a "Barão (1825) e Conde de São João das Duas Barras (1826), fidalgo cavaleiro da Imperial Casa, agraciado com a Grã-Cruz da Ordem Imperial do Cruzeiro, Comendador das de São Bento de Aviz e da Torre e Espada e condecorado com as medalhas das campanhas do Sul de 1811 a 1812 e 1815 a 1820" (ÉLIS, v. 5: 140).

Esse feitio louvatório e devoto do biógrafo ao biografado tem, de seu lado, um objetivo: "A Goiás cumpre não permitir que o esquecimento destrua esse vulto tão marcante da história Pátria (sic), cultuando sua memória por todas as formas possíveis” (ÉLIS, v. 5:142).

Assim, elaborada dentro da melhor tradição herdada do século XIX, a biografia de Xavier Curado narrada por Bernardo Élis permite um intertexto com as reflexões realizadas por Peter Gay sobre as funções do biógrafo:

Ao cumprir seu dever pedagógico, os biógrafos se juntavam aos conselheiros, avaliando as ansiedades provocadas por uma época de rápidas mudanças para enfrentá-las, e quem sabe dar-lhes remédio. Essas ansiedades perturbavam, agrediam, solicitavam, e entre eles os biógrafos narravam histórias inspiradoras, cheias de sentido moral. Nessa avalanche, alguns textos inculcavam piedade, outros o amor ao trabalho, outros ainda a abstinência sexual, ou tudo isso ao mesmo tempo (1999: 179).

O caráter didático e doutrinário das biografias servia como estímulo aos homens comuns: "não se podia esperar que os leitores ordinários repetissem em sua própria vida os êxitos de um estadista ou explorador, mas deviam inspirar-se neles, para poder alcançar metas elevadas" (GAY, 1999: 179).

Ao que responde perfeitamente a narração de Élis:

O exército nacional nascia da confluência dos sentimentos de independência, mas reunia em seu seio tanto pessoas bem educadas e bem formadas moralmente, até os mais ínfimos elementos, muitos deles, embora movidos pelo sentimento de patriotismo, portadores de sérias deformações morais. 
A não inclusão de Xavier Curado no ministério deve ser ainda levada à conta da conhecida modéstia desse goiano, aquela mesma modéstia que o fez pedir reforma tão cedo, reforma que foi negada pelo conde dos Arcos (1987, v. 5:133-134).

A heroicização, no caso da biografia de Xavier Curado, é acompanhada da tentativa de Bernardo Élis de conferir para Goiás o relevo que os fatos da Independência desmentiam:

Na cerimônia de coroação e sagração do Imperador Pedro I, a $1^{\circ}$ de dezembro de 1822, criava o Imperador a Ordem Imperial do Cruzeiro, em cuja primeira distribuição apenas duas Grã-Cruzes foram conferidas: ao Tenente-Coronel Xavier Curado e ao Dr. Antônio Carlos Ribeiro de Andrada Machado e Silva[...] Isso mostra bem que, dos militares, fora Xavier Curado quem melhores serviços prestara à grande causa e a ele foi destinada a primeira honrosa condecoração instituída pelo Imperador (ÉLIS, 1987, v. 5: 138).

Entre 1825 e 1826, o Imperador do Brasil conferiu ao General Xavier Curado os títulos nobiliárquicos de Barão e Conde: "Parece que sua modéstia e no seu afã de só importar-se com as coisas das armas, não se lembrou ele de obter seus brasões, pois o armorial brasileiro não o registrava" (ÉLIS, 1987, v. 5: 140). Como herói de primeira grandeza interessaria apenas a ação, não as comendas.

O nobre filho das terras goianas, como Élis assim o desenhou:

Na noite de 15 de novembro de 1830, quando entrava em ocaso a estrela de seu chefe e amigo Pedro I, envolvido definitivamente nas tramas do partido português e já profundamente indisposto com a causa nacional, falecia o ilustre goiano, o Tenente-General Xavier Curado, Barão e Conde de São João das Duas Barras, do Conselho de Sua Majestade e do de Guerra; fidalgo cavaleiro da Imperial Casa, Grã-Cruz da Ordem Imperial do Cruzeiro, Comendador das de São Bento de Aviz e da Torre e Espada e condecorado com as medalhas das campanhas do sul de 1811 a 1812 e 1815 a 1820 (1987, v. 5: 140). 
A pesquisa de Bernardo Élis sobre o general Xavier Curado não foi, no entanto, efetuada em fontes primárias, mas em livros de história do Brasil e de Goiás, em que comparecem autores de toda ordem. Só para se ter ideia: Alfredo Pretextado Maciel, Rocha Pombo e, especialmente, Gustavo Barroso, de quem cita páginas inteiras, talvez porque a historiografia deste se fazia de forma detalhada, puxando ou imaginando as cenas, os diálogos, as resoluções, a psicologia do personagem, num feitio bastante ficcional, feitio que Bernardo Élis assume, na medida em que se utiliza de "respostas" de Xavier Curado, indica sua própria dedução sobre os feitos do biografado - " é de se crer que” - , indica “pensamentos", ideais e ações de Xavier Curado etc.

De outro lado, justifica eventos - como o fato de Xavier Curado não ter recebido a pasta de guerra quando o Príncipe Regente criou seu novo ministério em janeiro de 1822, porque Xavier Curado era brasileiro e só um brasileiro poderia figurar nesse ministério e esse era José Bonifácio de Andrada e Silva; defende Xavier Curado como o Criador do Exército Brasileiro, sobre o que transcreve alguns depoimentos de historiadores; projeta o seu modo constante e firme de atuar, com a reprodução do slogan que lhe comandava a postura: era filosofia de Xavier Curado " conhecer o momento exato em que era chegada a vez de as forças realizarem o que antes era simples desejo ou ideia" (ÉLIS, 1987, v. 5: 123); tece comentários à parte do que descreve, como quando compara os métodos das guerrilhas e andanças de Artigas com a Coluna Prestes de um século depois (1923/4).

O sentido do texto não é literário e seu objetivo, portanto, é historiográfico, dentro de uma história praticada nos paradigmas do final do século XIX: história política elaborada por indivíduos "sagazes", sem análise ou problemas, centrada em homens e vultos heróicos, com intuito sobretudo moral e exemplar, capaz de assentar uma história para Goiás.

De seu lado, em relação à História do Brasil, a formação de uma cultura histórica sobre Goiás pouco espaço teve e ainda hoje perde espaço de forma acentuada. Fala-se de história do Brasil como se Goiás estive alheio aos eventos nacionais ou neles participasse de forma diminuta. A reprodução da história nas escolas ainda segue uma base centralizadora: o Sudeste como inventor da nação.

Nesse sentido, o projeto biográfico de Bernardo Élis é instigante e ao mesmo tempo curioso. 
Antecipado em 50 anos, o resgate da história de Goiás pela via da biografia é uma ferramenta na luta contra o descaso e o esquecimento. Quando inicia sua análise do poeta goiano Félix de Bulhões, assinala:

Quem se der ao trabalho de examinar a história de Goiás ficará impressionado com a falta de memória histórica sobre seus principais vultos. Homens que gozaram de imensa popularidade em várias épocas jazem no mais negro esquecimento. Nós, que nascemos e temos vivido em Goiás, podemos fazer uma rememoração para constatar que não nos lembramos de quase nenhuma festividade ou solenidade comemorativa das datas ou dos vultos históricos de nossa terra" (ÉLIS, 1987, v. 4: 4).

A curiosidade reside em um projeto ousado nos seus limites. Não se lida com uma simples biografia de Xavier Curado, mas antes de tudo com uma vontade de sua patrimonialização por parte de Bernardo Élis. Seria a construção de uma memória como subsídio à identidade de Goiás:

A Goiás cumpre não permitir que o esquecimento destrua esse vulto tão marcante da história Pátria, cultuando sua memória por todas as formas possíveis. E dentre elas a mais eficiente seria a de se mandar erigir uma estátua, num dos lugares mais centrais de nossa capital, para fixar de uma vez por todas na lembrança dos pósteros a imagem desse filho de Goiás, a quem a pátria deve a criação do exército nacional. Que a iniciativa desse concurso seja o passo inicial da ereção do monumento ao Tenente-General Joaquim Xavier Curado (ÉLIS, 1987, v. 5: 143).

\section{A patrimonialização de Xavier Curado}

A "patrimonialização"11 de Xavier Curado e a edificação de sua estátua seriam o primeiro passo na construção da cultura histórica de Goiás e permitiriam a formação de uma propriedade coletiva (REVEL, 2010) dos goianos.

Se retomamos, por comparação, a década de 1980 na França, esta foi marcada por um tripé: comemoração, patrimônio e identidade. O projeto de Élis antecipa-se em uma

\footnotetext{
${ }^{11}$ Entendemos o conceito de "patrimonialização", nesse caso em particular, como a interface entre História e Memória, visando a construção de um(a) sentido/narrativa para o estado de Goiás.
} 
década ao caso francês. Como salienta Revel (2010), a preservação "dos passados" é um tropos de muitas sociedades. No caso goiano, a proposta de Élis passou inócua e ao largo da sociedade. Como simples paralelo e guardada as devidas proporções, Revel (2010) aponta que a noção de uma amnésia histórica foi diagnosticada na França: as gerações mais novas perdiam os laços com o passado francês. A leitura da crise de consciência histórica traduzia-se em crise de identidade:

Pierre Nora lembrava justamente que nós trabalhamos com afinco para organizar o passado que ele se tornará um dia. Sem dúvida não somos nós os primeiros a nos preocupar com o que deixaremos para trás. Mas somos talvez os primeiros a querer prevenir também radicalmente o trabalho de decantação do tempo. Ainda vivos, nós nos enterramos na história (REVEL,2010: 259).

O esforço da patrimonialização de Xavier Curado foi primeiramente apresentado ainda em 1921 (ÉLIS, 1987) pelo proto-historiador goiano Americano do Brasil, ao apresentar um projeto de lei para construção de um busto em homenagem a Xavier

Meu projeto, Sr. Presidente, manda perpetuar em bronze, em proporções de simples busto, um dos maiores brasileiros, desconhecido entretanto, uma das grandes figuras da história sul-americana, justamente recomendado pela máxima influência que exerceu nas peripécias de nossa integridade territorial e nos momentos mais agitados da grande causa de 1822 (BRASIL apud ÉLIS, 1987, v.5: 141).

Embora tenha sido aprovado, o busto não foi construído. Os goianos teriam apenas um retrato a óleo de Xavier Curado, oferecido por Alfredo d'Escragnole Taunay:

Perdida essa tela, depois de 50 anos, em péssimo estado, por uma notável coincidência, veio ter em minhas mãos, tendo feito extrair da mesma várias cópias que tenho dado à publicidade e oferecido a nossas instituições, guardadoras das tradições da pátria. E é para que não se perca, como aconteceu a Gonçalves Ledo, a verdadeira imagem do herói e também para concorrer com uma ideia à celebração das glórias da independência, que venho pedir à câmara sua perpetuação em bronze, o qual levará aos vindouros um exemplo 
de eloquente patriotismo e uma representação de nossa imorredoura saudade (BRASIL apud ÉLIS, 1987, v. 5: 142).

Na visão de Élis, o esforço de Americano do Brasil foi vital para a permanência, ainda modesta, da imagem de Xavier Curado. "O retrato original está guardado no Instituto Histórico e Geográfico do Rio de Janeiro" (ÉLIS, 1987, v. 5: 142). Quando da publicação do número 2 e volume XV da Informação Goyana, a imagem de Curado foi estampada na ocasião do centenário de sua morte, lembrado em 1930. Americano do Brasil assim descreve o general em sua representação:

Apesar dos grandes estragos desse esboço, as feições do grande morto estão claramente visíveis. A tela representa o General Curado em meio corpo, trajando o fardão de tenente-general. É um vulto magro mas bem proporcionado: cabeça quadrilonga, testa saliente, cabelos raros, olhos azuis, nariz romano, molares saliente, pêlos totalmente raspados, feições calmas mas enérgicas (BRASIL apud ÉLIS, 1987, v. 5: 143).

O herói se manifesta e se faz presente em sua grandeza pela tela a óleo. "Nariz romano" e "feições calmas, mas enérgicas", oferecem a imagem grandiosa de Curado. O fetiche e a sacralização se realizam em tela e papel: o quadro e a biografia escrita por Élis edificam o vulto do grande goiano. A escrita de Élis é um projeto que se manifesta como dever de memória e dever de história (REVEL, 2010). O passado deve ser lembrado, deve se fazer presente, orientando as gerações futuras e mantendo os laços identitários. A biografia nesse caso é uma ferramenta de heroicização e elaboração de uma cultura histórica dos goianos.

\section{O biógrafo e a autolegitimação}

A eleição de Bernardo Élis para a Academia Brasileira de Letras deu-se em 23 de outubro de 1975. As palavras de sua posse no dia 10 de dezembro de 1975 evocam uma relação com a terra natal - Corumbá de Goiás - em uma leitura superestimada do ethos goiano: "como nas Minas Gerais, em Corumbá convive harmoniosamente a cultura nativa, cabocla ou popular, com a de cunho europeu e Universal" (ÉLIS, 1987, v. 4: 20). Leitura complicada da cultura goiana: seria, talvez, uma busca pela cordialidade e 
virtuosismo dos goianos numa região de fronteira na qual modernidade e tradição se complementam, espaço de trocas afetivas e de reciprocidade.

Mais adiante, ao refletir sobre a passagem do século XVIII para o XIX, nova demonstração de exaltação ao dizer que os goianos "criaram um ambiente de respeito, amor e interesse pelas coisas do espírito e da inteligência, especialmente na capital da província" (ÉLIS, 1987, v. 4: 25). Ao citar o poeta goiano Antônio Félix de Bulhões Jardim e Hugo de Carvalho Ramos em seu discurso de posse, nota-se o desejo de legitimar a sua própria entrada no campo literário (BOURDIEU, 2011) nacional. A inserção no campo literário não é fruto apenas da própria obra do literato, porque as palavras não rompem os limites do campo, ou seja, as ideias não objetivam a ascensão do escritor. É fundamental identificar que há, em toda época, uma demanda esperada, um habitus desejado, como ferramentas de aceitação pelos pares. O campo literário se faz pela luta por legitimidade:

Todas as posições dependem, em sua própria existência e nas determinações que impõem aos seus ocupantes, de sua situação atual e potencial na estrutura do campo, ou seja, na estrutura da distribuição das espécies de capital (ou de poder) cuja posse comanda a obtenção dos lucros específicos (como o prestígio literário) posto em jogo no campo (BOURDIEU, 1996: 261).

Fato outro é a mobilização de Élis na busca de legitimidade no campo intelectual quando da escrita da biografia de Xavier Curado. Como apêndice da obra, Bernardo realiza uma extensa genealogia que busca reatar passado e presente, tendo como norte a figura do Tenente-General Xavier Curado. Em apêndice intitulado "Parentes do General Joaquim Xavier Curado", os nomes de políticos, jornalistas e escritores da estirpe do patrono do Exército Nacional inclui também Bernardo Élis Fleury de Campos Curado. Figuras outras, como os políticos Leopoldo de Bulhões, Guimarães Natal, Emival Caiado são membros da vasta parentela e a classe literária goiana também nasce da mesma fonte: Erico Curado (pai de Élis), Gilberto Mendonça Teles, Americano do Brasil, Henrique Silva e outros compõem a plêiade.

Podemos perceber um esforço de Élis por se manifestar em seu biografado, melhor dizendo, Xavier Curado seria não apenas um parente, mas, antes de tudo, uma fonte de legitimidade da imagem refletida de Élis. O posto de destaque do militar nas lutas pela formação da emancipação, seriam agora travadas por Élis, na emancipação e difusão da 
própria literatura goiana, representada na sua pessoa. Se a corte imperial recebeu Xavier Curado, Élis buscava ser recebido na corte da literatura. Curioso caso de biografia com pretensões autobiográficas. Na busca por reconhecimento ao olhar dos outros (CALLIGARIS, 1998), Élis constrói a si mesmo pela atuação indireta de seu parente distante. A campanha pela eleição para a Academia Brasileira de Letras materializa-se na biografia de Xavier Curado quando das comemorações do Sesquicentenário da Independência. Goiás buscava novamente sua inserção na História do Brasil.

\section{Fontes}

ÉLIS, Bernardo (1987). Alma de Goiás, volumes 4 e 5. Rio de Janeiro: José Olympio. Acervo Bernardo Élis. Centro de Documentação Alexandre Eulálio. Instituto de Estudos da Linguagem, Unicamp.

Oeste (2001). - Revista Mensal. [Livro em CD-Rom]. Agência Goiana de Cultura "Pedro Ludovico Teixeira" - AGEPEL.

\section{Referências Bibliográficas}

ALMEIDA, Adjovanes Thadeu Silva (2009). O regime militar em festa: a comemoração do sesquicentenário da independência brasileira (1972). (Tese de Doutorado em História). Universidade Federal do Rio de Janeiro, Rio de Janeiro.

ARFUCH, Leonor (2010). O espaço biográfico. Rio de Janeiro: UERJ.

BOURDIEU, Pierre (1996). As regras da arte: gênese e estrutura do campo literário. São Paulo: Cia. Das Letras.

A ilusão biográfica. In: AMADO, Janaína \& FERREIRA, Marieta de Moraes. Usos e abusos da História oral. Rio de Janeiro: Editora FGV, 2006. (2010) O poder simbólico. Rio de Janeiro: Bertrand Brasil. (2011) A economia das trocas simbólicas. São Paulo: Perspectiva.

CALLIGARIS, Contardo (1998). Verdade de autobiografias e diários íntimos. In: Estudos históricos. № 21 . Rio de Janeiro.

GAY, Peter (1999). A experiência burguesa: da Rainha Vitória a Freud - O coração desvelado, volume 4. São Paulo: Companhia das Letras.

HOBSBAWM, Eric \& RANGER, Terence (2008). A invenção das tradições. São Paulo: Paz e Terra.

LORIGA, Sabina (1998). A biografia como problema. In: REVEL, Jacques (Org.). Jogo de escalas: a experiência da microanálise. Rio de Janeiro: Editora Fundação Getúlio Vargas, pp. 225-250.

MOREYRA, Sérgio Paulo (1972). O processo de independência em Goiás. In: MOTA, Carlos Guilherme. 1822: dimensões. São Paulo: Perspectiva.

MOTA, Carlos Guilherme (1972). 1822: dimensões. São Paulo: Perspectiva. 
NORA, Pierre (1993). Entre memória e história: a problemática dos lugares. Revista do Programa de Estudos Pós-Graduados em História e do Departamento de História. São Paulo, n.10, 1993, pp. 7-28.

NOVAIS (2011), Fernando. Portugal e Brasil na Crise do Antigo Sistema Colonial (1777-1808). São Paulo: Hucitec.

REVEL, Jacques (2010). História e historiografia: exercícios críticos. Curitiba: Editora UFPR, 2010.

TELES, José Mendonça (2000). Dicionário do escritor goiano. Goiânia: Editora Kelps.

UNES, Wolney (Org.) (2005). Bernardo Élis. Vidas em obras. Goiânia: AGEPEL: Instituto Centro-Brasileiro de Cultura.

VICENTINI, A. (2005). Bernardo Élis revisitado. In: UNES, W. Bernardo Élis - vida em obras. Goiânia: ICBC/Agepel.

WHITE, Hayden. (1995). Meta-história: a imaginação histórica do século XIX. São Paulo: Editora da Universidade de São Paulo.

GOMES, Modesto e MOTA, Ático Vilas Boas da (1969). Aspectos da cultura goiana. Goiânia: Dec/Oriente.

Artigo recebido em 08 de agosto de 2016.

Aprovado em 31 de outubro de 2017. 